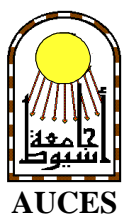

\title{
ASSESSMENT OF AN EDUCATIONAL TRAINING PROGRAM FOR NURSES WORKING IN MATERNAL AND CHILD HEALTH (MCH) CENTERS IN ASSIUT CITY REGARDING INFECTION CONTROL
}

\author{
Assma Kamal Hassan ${ }^{*}$, Farag Mohamed Moftah ${ }^{* *}$, Sawsan Mohamed Alaa El-Din ${ }^{*}$ \\ and Soad Sayed Bayomi*
}

*Dept. of Community Health Nursing, Faculty of Nursing and **Dept. of Community Medicine, Faculty of Medicine Assiut University

\begin{abstract}
:
The aim of this study was to assess an educational training program for nurses working in $\mathrm{MCH}$ centers in Assiut regarding infection control. The study was conducted in all maternal and child health centers (MCH) in Assiut City. The total number of the study sample in all $\mathrm{MCH}$ centers was72 nurse. There were two tools used for data collection: a structured interview questionnaire and an observation checklist. The structured interview questionnaire was used before and after the program to measure the exact level of knowledge that nurses have about infection such as (definition of sterilization, proper isolation, good infection control, types of sterilization, equipment that may be sterilized in autoclave(6 questions).It also assesses nurses knowledge about universal precaution related to blood and body fluids (16 questions) and their knowledge about hand washing (3 questions). The second tool is an observation checklist that was developed for assessing nurses' performance. Data were collected during the period from the beginning of January 2003 to October 2003. Each center consumed two months. Results of this study indicated that nearly half (48.6\%) of the sample were in the age group $20-30$ years, $45.8 \%$ were over 30 years. All nurses lacked knowledge related to the concept of epidemiology only $40.2 \%$ of the nurses under the study had sufficient knowledge regarding the concept of epidemiology before exposure to the program. The percentage increased to $\mathbf{8 8 . 9 \%}$ after administration of the program. Also the majority of nurses had proper hand washing techniques on the post test with a statistical significant difference of $<0.01$. As for nurses' knowledge of the occupational hazards to which they may be exposed during work in $\mathrm{MCH}$ centers, the majority of nurses mentioned needle stick, followed by the amount of blood splattering from the patient on their hands, patient sneezing or coughing and touching patient skin. Nurses play an important role in (MCH) centers to minimize and prevent infection through providing the nurses with adequate and appropriate supplies which include protective clothes and equipment in health care settings.

Conclusion; low frequency of correct answer was observed among nurses in the pre test, the prevalence of correct answer was increased in the post test related to knowledge and practice.

Recommendations; periodic refresher in-service training courses should be provided to nurses in order to keep them of up dating knowledge and practice regarding to infection control.
\end{abstract}




\section{INTRODUCTION:}

Infection control is a quality standard of patient care and is essential for the well being of the patients and the safety of both patients and staff. To accomplish a reduction in infection rates, an infection control program has to be given a high standard structure (Hambraeus, 1995).

Infection is caused by organisms which invade the hosts, immunological defense mechanisms, although susceptibility to infection may vary from person to person. The risk of infection is increased if the patient is immunocompromised by age, neonates and the elderly are more at risk due to their less efficient immune system underlying disease, for example, those patients with sever debilitating or malignant disease and patients undergoing surgery or instrumentation (Gould, 1994). Disinfection describes a process that eliminates many or all microorganisms with the exception of bacteria spores from inanimate objects. This is generally accomplished by the use of a chemical disinfectant or wet pasteurization. Examples of disinfectants are alcohols, chlorine and phenols (Rutala and Shafer, 1996)

The primary aim of an infection control program, whether in the community or hospitals, is to prevent people from acquiring avoidable infection. Achieving this aim requires the willingness of all health care staff to maintain the highest possible standards of clinical practice and follow sound infection control principles. Unfortunately, there are even today, some method used to control infection which are based on tradition but which have little effect on cross infection rates (Griffiths and Ward, 1995)

In Egypt sixty maternal deaths associated with sepsis were recorded in the 1992-1993 (National Survey of Maternal Mortality, 1994). These deaths represented $12 \%$ of all direct obstetric deaths and $8 \%$ of all maternal deaths. The national maternal mortality study in 1992 1993 estimated that the Maternal Mortality Ratio (M.M.R) was 174/100,000.

The term universal precaution means taking routine safe working practice to protect nurses and patients from infection by blood and body fluids. HBV among other disease can be transmitted by infected blood (Department of Health, 1991). There are many blood born diseases, known and unknown; so safe working practice means taking care at all times with all patients. All blood and body fluids should be treated with care since they are all potential infection risks. Any individual could carry any blood born disease, so it makes sense to have standard protocols and to make risk assessments of procedures. These risk assessments are necessary as part of safe working under the control of substance health hazard regulations (Health and Safety Executive, 1989).

Effective training is essential to ensure that these concepts are understood and put into practice wherever health care is provided. Nursing staff must be educated in the basic principles of infection control and acquire new knowledge and skills because the quality of nursing care depends to a large degree on the knowledge, skills, attitudes and activities of the 
practicing nursing staff. Many health care workers have been involved particularly over the last few years in setting standards for clinical practice. Where the standards required infection control input, the infection control nurse was often asked to contribute. However, situations have occurred where this advice has neither been sought nor been available (WHO, 1991).

The nurses Play a critical role in controlling infection that begins with early detection and surveillance technique. The extent of the nursing intervention is determined by the susceptibility of the host, the virulence and susceptibility the organism to antibiotics and the client's signs and symptoms (Taylor et al., 1997).

The infection control nurse is expected to perform all functions necessary for the total care of the patients. She must know how to protect others from contracting the disease, and she is responsible for disseminating prevention and control information to personnel, patients, their families and visitors (Jewish, 1997).

The aim of this study is to assess an educational training program for nurses working in MCH centers in Assiut regarding infection control.

\section{SUBJECTS AND METHODS:}

\section{Setting:}

This study was conducted in all maternal and child health centers (MCH) in Assuit City (Kulta, Kedwany, El-Walidia, El-Arbaen and El-Hamara). The work system in MCH centers is divided into two shifts; morning and afternoon except El-walidia center which provide services for 24 hours a day.

\section{Sample:}

The total number of the study sample in all MCH centers were 72 nurse. All nurses included in the study.

- Kulta : 10 nurse

- Kedway : 11 nurse

- El-Walidia : 18 nurse

- El-Arbeen : 19 nurse

-El-Hamara : 14 nurse

-Total : 72 nurse

-Tools: There are two tools: were designed specifically to collect data of the present study.

\section{A- The first tool (Knowledge):}

A proper questionnaire was used as a tool for data collection in both pre \&post test of the training program, in order to measure the knowledge level of the trainees about the concerned subject about infection control and the nurses needed and to evaluate the gaining knowledge after the program by using the same tool. The questionnaire consisted of two parts:

The first part is concerned with: The demographic characteristics of nurses'(age, marital status, years of experience, and qualification degree).

The second part (Nurses knowledge regarding infection control); it included the following: Definition of sterilization, proper isolation, good infection control, types of sterilization, equipment that may be sterilized in autoclave (6 questions)

-Knowledge about universal precaution related to blood and body fluids in (MCH) centers such as precaution inside and outside lab, cleansing the blood, the presence of abrasions or superficial wounds, the method of sending linens from the ward to the laundry,...etc. (16 questions).

-Knowledge about hand washing. It is important to dry hands and to know about 
health hazards to which nurses may be exposed during working in MCH centers (3 questions)

\section{B-The second tool for nurses (chick-list):}

An observation checklist was developed for assessing nurses' performance. This tools was used before and after the program to evaluate the extent to which the training program affected the nurses' performance. The observation chick list included: When nurses should wash their hands, a solution that may be used in hand washing, equipment that may be used in hand washing, wearing gloves, face mask, and plastic apron that should be put on and the methods of disposing wastes after wound dressing...etc (12 questions) ;observation was done during routine work.

C- A Booklet of health team program about infection control in MCH centers in Assiut city. It includes:

1-Definition of infection, types of sterilization.

2-Mode of transmission of infection, types of sterilization, equipment may be sterilized in autoclave.

3-Universal precaution related to infection and puncture of the skin.

4-Universal precaution related to blood and body fluids.

5-Practices about infection control such as method of hand washing, types of gloves, mask and plastic apron that should be put on.

6-The method of disposing wastes after wound dressing and universal precaution related to blood and body fluid inside and outside lab.

7-The role of hands in cross infection when it would be essential to decontaminate hands. Demonstration with opportunity for practice with feedback.

8-The risk occurring from contact with blood and body fluids and safe sharps handling and disposal. The main topics covered are organizational policy, environmental hygiene, skin integrity, hand hygiene, protective equipment, spillage, waste disposal, sharps disposal, needle stick injury and mucous membrane splashes.

9-The booklet was distributed for all studied group.

\section{Methods:}

1-A pilot study: After developing the tools, a pilot study was conducted on one center for all nurses to assess the validity of the tools and clarity of the questions.

2-Data were collected during the period from the beginning of January 2003 to October 2003. Each center consumed two months. The methods of teaching used in the program were lecturing followed by focus group discussions in addition to audiovisual materials, and demonstrations for healthy practices. The details of the program and content are included in booklet. Arabic version of the program is contain.

The expected duration for the filling of different activities sheet were:

1-The structured interview questionnaire for measuring the nurses' Knowledge (preposttest) consumed on average about 30 minute.

2-The observation check list for monitoring the nurses skills consumed about 45 minutes. The investigator monitored the actual performance of nurses during the working times for all procedures.

The total time needed for monitoring the two activities for each nurse consumed about 75 minutes. The investigator monitored the work of 3 nurses per day. 
Analysis of Data: The obtained data were analyzed and tabulated. Descriptive statistics as frequency distribution, percentage, and test of significance ắ- P-value of $\leq$ less than 0.05 considered as statistically significant.

\section{RESULTS:}

Table (1) shows the demographic characteristics of nurses. Nearly half of the sample there age ranged from 20- 30 years. As regard marital status $18.05 \%$ of nurses were single, 80 . $5 \%$ were married and only $1.38 \%$ were divorced. As regards years of experience $31.9 \%$ had less than 5 years e, $33.3 \%$ their period of experience ranged between 5-15 years, and $34.7 \%$ had experience above 15 years. In relation to qualification degree $93.05 \%$ had diploma of nursing, compared with $6.9 \%$ who had midwifery degree.

Table (1): Demographic characteristics of nurses in (MCH) centers in Assiut City.

\begin{tabular}{|c|c|c|}
\hline Characteristics & No & $\%$ \\
\hline \multicolumn{3}{|l|}{ 1- Age: } \\
\hline$<\mathbf{2 0}$ & 4 & 5.6 \\
\hline $20-30$ & 35 & 48.6 \\
\hline $30+$ years & 33 & 45.8 \\
\hline \multicolumn{3}{|l|}{ 2- Marital status: } \\
\hline & 13 & 18.0 \\
\hline Single & 58 & 80.6 \\
\hline & 1 & 1.4 \\
\hline \multicolumn{3}{|l|}{ Married } \\
\hline Divorced & 23 & 31.9 \\
\hline 3-Years of experience: & 24 & 33.3 \\
\hline$<$ 5years & 25 & 34.7 \\
\hline $5-15$ years & & \\
\hline $15+$ years & 72 & 100 \\
\hline 4- Sex : & - & - \\
\hline Female & & \\
\hline Male & 67 & 93.0 \\
\hline 5- Qualification degree: & 5 & 6.9 \\
\hline Diploma & & \\
\hline Midwives & & \\
\hline Total & 72 & 100.0 \\
\hline
\end{tabular}

Table (2) shows the percent distribution of correct knowledge about infection control among nurses' in MCH center in Assiut city. Frequency of correct answer about proper isolation, good infection control and equipment may be sterilized in Autoclave among nurses was $(81.9 \%, 75 \%, 88.8 \%)$ respectively on pre test compared to $(100 \%, 81.9 \%, 94.4 \%)$ respectively in post test. On pre test the correct answer of nurses about universal precaution to blood and body fluid; was $12.5 \%$ about precaution related to blood and body fluid, $56.9 \%$ about the method of sending solid linen from the word to the laundry. As regard post 
test the result present that $(80.5 \%, 84.7 \%)$ to the same items. There is highly significant difference between pre and post test of nurses (p-value $<0.01$ ).

Table (3) shows statistical significant difference were found related to correct practices and the test related of items" wash their hands, Solution may be used in hand washing, Equipment may be use in hand washing, Technique of hand washing among nurses in the pre-test showed that $(87.5 \%$, $68.05 \%, \quad 84.7 \%, \quad 33.3 \%, \quad 34.7 \%$ ). After application of the program, the nurses practice for the same items improved $(\mathbf{1 0 0 \%}$, $100 \%, 95.8 \%, 76.3 \%$ and $81.9 \%$ ).

Table (2): Distribution of correct knowledge about infection control among nurses in (MCH) center in Assiut City

\begin{tabular}{|c|c|c|c|c|c|}
\hline \multirow{2}{*}{ Items } & \multicolumn{2}{|c|}{ Pre test No. $=72$} & \multicolumn{2}{|c|}{ Post test No. $=72$} & \multirow{2}{*}{$P$ value } \\
\hline & No & $\%$ & No & $\%$ & \\
\hline $\begin{array}{l}\text { Knowledge about infection control: } \\
\text { 1-Define the following: }\end{array}$ & & & & & \\
\hline - Good sterilization & 33 & 45.8 & 48 & 66.7 & $<0.01$ \\
\hline - Proper isolation & 59 & 81.9 & 72 & 100 & $<0.01$ \\
\hline - Good infection control & 54 & 75 & 59 & 81.9 & $>0.5 \mathrm{NS}$ \\
\hline 2-Type of sterilization & 6 & 8.3 & 45 & 62.5 & $<0.01$ \\
\hline 3-Equipment may be sterilized in autoclave & 64 & 88.9 & 68 & 94.4 & $>0.36 \mathrm{NS}$ \\
\hline 4- Mode of transmission of infection & 29 & 40.3 & 64 & 88.9 & $<0.01$ \\
\hline $\begin{array}{l}\text { Knowledge about universal precaution to blood } \\
\text { and body fluid Precaution related to blood and } \\
\text { body fluid }\end{array}$ & 9 & 12.5 & 58 & 80.6 & $<0.01$ \\
\hline Cleansing the blood & 70 & 97.2 & 72 & 100 & $<0.05$ \\
\hline $\begin{array}{l}\text { The presence of abrasions or superficial wound } \\
\text { endangers }\end{array}$ & 67 & 93.1 & 71 & 98.6 & $>0.2109 \mathrm{NS}$ \\
\hline $\begin{array}{l}\text { The method of sending solid linens from the } \\
\text { word to the laundry }\end{array}$ & 41 & 56.9 & 61 & 84.7 & $<0.01$ \\
\hline Cleansing and sterilizing surgical instruments & 70 & 97.2 & 72 & 100 & $<0.01$ \\
\hline
\end{tabular}

Table (3): Distribution of nurses' practices about infection control in $(\mathrm{MCH})$ centers in Assiut City. No $=72$

\begin{tabular}{||l|c|c|c|c|c||}
\hline \multicolumn{1}{|c|}{ Items } & \multicolumn{2}{c|}{ Pre test } & \multicolumn{2}{c|}{ Post test } & \multirow{2}{*}{ P value } \\
\cline { 2 - 6 } & No & $\%$ & No & $\%$ & \\
\hline $\begin{array}{l}\text { Nurses practice about infection control } \\
\text {-Wash their hands. }\end{array}$ & 63 & 87.5 & 72 & 100 & $<0.05$ \\
\hline -Solution may be used in hand washing. & 49 & 68.1 & 72 & 100 & $<0.01$ \\
\hline - Equipment may be use in hand washing. & 61 & 84.7 & 69 & 95.8 & $<0.05$ \\
\hline - Technique of hand washing.. & 24 & 33.3 & 55 & 76.4 & $<0.01$ \\
\hline - Wear of gloves. & 68 & 94.4 & 71 & 98.6 & $>0.36$ \\
\hline -Wear of face mask. & 25 & 34.7 & 59 & 81.9 & $<0.01$ \\
\hline - Wear of Plastic apron. & 49 & 68.1 & 66 & 91.7 & $<0.01$ \\
\hline - Disposing wastes after wound dressing. & 31 & 43.1 & 65 & 90.3 & $<0.01$ \\
\hline - Disposing gloves and used mask. & 54 & 75 & 67 & 93.1 & $<0.01$ \\
\hline $\begin{array}{l}\text { - Perform sterilization for appropriate temperature and } \\
\text { time enough for sterilizing metal instruments with vapor. }\end{array}$ & 22 & 30.1 & 64 & 88.9 & $<0.01$ \\
\hline
\end{tabular}


Ass. Univ. Bull. Environ. Res. Vol. 7 No. 2, October 2004

\begin{tabular}{||l|c|c|c|c|c||}
\hline $\begin{array}{l}\text { - Using appropriate time for sterilizing metal instruments } \\
\text { with vapor. }\end{array}$ & 28 & 38.9 & 45 & 62.5 & $<0.01$ \\
\hline $\begin{array}{l}\text {-Using appropriate temperature for sterilizing instruments } \\
\text { with vapor. }\end{array}$ & 16 & 22.2 & 53 & 73.6 & $<0.01$ \\
\hline
\end{tabular}

1-P value $<0.01$ Highly Significant

2-P value $<0.05$ Significant at $5 \%$

3-P value at $5 \%$ NS (not significant) 
Table(4) shows the nurses responses related to occupational health hazards due to exposure during work in MCH centers. The majority of nurses mentioned needle stick, blood splattering from the patient on thier hands, patient sneezing or coughing and touching patient skin $(97.2 \%, 79.2 \%, 95.8 \%, 100 \%$ and $94.4 \%)$ respectively.

Table (5) shows distribution of nurses and midwives knowledge about infection as regard to qualification. Before exposure to the program showed that $(80.6 \%, 67.2 \%, 88.5 \%$,
97\%, $75 \%$ and $86.5 \%$ ) had correct answer about isolation, good infection control, what is the equipment may be sterilized in Autoclave, cleansing the blood, the methods of sending solid linen from the ward to the laundry and when should health team wash their hands. In post test improved nurses knowledge about the same items $(100 \%, 92.5 \%, 95.5 \%, 100 \%, 94.3 \%$ and100\%) respectively. Furthermore midwives had lack knowledge before exposure the program while improved after the program about the same items.

Table (4) : Nurses' responses related of occupational hazards in MCH Centers.

\begin{tabular}{||l|c|c||}
\hline \multicolumn{1}{|c|}{ Items } & \multicolumn{2}{c||}{ Nurses N=72 } \\
\cline { 2 - 3 } & No & $\%$ \\
\hline Needle stick & 70 & 97.2 \\
Feeding patient & 24 & 33.3 \\
Bed making & 28 & 38.9 \\
Blood splattering from the patient on their hands & 57 & 79.2 \\
Blood splattering from the patient on an open wound in your hands & 69 & 95.8 \\
Patient sneezing or coughing & 72 & 100 \\
Touching patient skin & 68 & 94.4 \\
Blood splattering on your eyes & 17 & 23.6 \\
\hline
\end{tabular}

Table (5) Distribution of nurses and midwives knowledge about infection as regard to qualification.

\begin{tabular}{|c|c|c|c|c|c|c|c|c|c|}
\hline \multirow{3}{*}{ Qualification } & \multicolumn{4}{|c|}{ Pretest } & \multicolumn{4}{|c|}{ Post test } & \multirow{3}{*}{$P$ value } \\
\hline & \multicolumn{2}{|c|}{$\begin{array}{l}\text { Nurses } \\
\text { No. }=67\end{array}$} & \multicolumn{2}{|c|}{$\begin{array}{l}\text { Midwives } \\
\text { No. }=5\end{array}$} & \multicolumn{2}{|c|}{$\begin{array}{l}\text { Nurses } \\
\text { No. }=67\end{array}$} & \multicolumn{2}{|c|}{$\begin{array}{l}\text { Midwives } \\
\text { No. }=\mathbf{5}\end{array}$} & \\
\hline & No. & $\%$ & No. & $\%$ & No. & $\%$ & No. & $\%$ & \\
\hline Sterilization & 29 & 43.3 & 1 & 20.0 & 52 & $\mathbf{7 7 . 6}$ & 3 & 60.0 & $<0.01$ \\
\hline Isolation & 54 & 80.6 & 4 & 80.0 & 67 & 100 & 4 & 80.0 & $<0.01$ \\
\hline Good infection control & 45 & 67.2 & 3 & 60.0 & 62 & 92.5 & 4 & 80.0 & $<0.01$ \\
\hline Types of sterilization & 6 & 8.9 & - & 0.0 & 43 & 64.2 & 3 & 60.0 & $<0.01$ \\
\hline $\begin{array}{l}\text { What is the equipment may be sterilized } \\
\text { in Autoclave }\end{array}$ & 59 & 88.5 & 5 & 100 & 64 & 95.5 & 5 & 100 & $<0.01$ \\
\hline Mode of transmission of infection & 28 & 41.8 & 1 & 20 & 60 & 89.5 & 3 & 60.0 & $<0.01$ \\
\hline Universal precaution inside lab. & 7 & 10.4 & 2 & 40 & 54 & 80.6 & 2 & 40.0 & $<0.01$ \\
\hline Cleansing the blood & 65 & 97.0 & 2 & 40 & 67 & 100 & 4 & 80.0 & $<0.01$ \\
\hline $\begin{array}{l}\text { The methods of sending solid linen from } \\
\text { the word to the laundry }\end{array}$ & 50 & 75.0 & - & 0.0 & 63 & 94.3 & 2 & 40.0 & $<0.01$ \\
\hline $\begin{array}{l}\text { When should health team wash their } \\
\text { hands }\end{array}$ & 58 & 86.5 & 4 & 80 & 67 & 100 & 5 & 100 & $<0.01$ \\
\hline
\end{tabular}

1-P value $<0.01$ Highly Significant

$2-\mathrm{P}$ value $<0.05$ Significant at $5 \%$

3-P value at $5 \%$ NS (not significant) 


\section{DISCUSSION:}

Prevention of infection is within the nurses' scope of practice. Thus, knowledge and awareness of infection control principles equip the nurse with the ability to face dilemmas and make the choice that can prevent nosocomial infection (Thomllison et al, 1993).

The present study revealed that nurses' knowledge related to epidemiology before the program was very limited $\mathbf{( 4 0 . 2 \% )}$. However, after the administration of the program it increased to $88.8 \%$. This indicates that the implementation of the program was very effective in enhancing nurses' knowledge and performance. This is in agreement with some researches indicated that results (Turner et al, 1990).

The association between hand hygiene and the prevention of infection was established many years ago. The link between failure to wash hands and the development of sepsis was original (Iganz, 1994).The present study showed that most nurses generally did not give correct answer related to hand washing on pre test. Moreover, Ghallab(1994) and El-ewy, (1997) findings are consistent with our findings regarding lack of health team knowledge about hand washing.

CDC, (2002) reported that bacterial transfer occurs more readily between wet surfaces than dry ones. Subjects were asked to grasp fabric-covered bottles which had been contaminated with bacteria when the hands were moist. $85 \%$ of all the organisms were transferred to them from the fabric.

This is in accordance with the findings of Hill, (1992) and Colleg, (1994) who stated that the nurses believed that if their hands are not physically soiled, no spread of infection can occur. (Nicholson 1997 and Mickos-schild, 1998) stated proper hand washing technique is the single most effective infection control measures.
As regard to hand washing technique the present study revealed nurses' practice had low frequency of correct practice was observed among nurses in the pre test $(33.3 \%)$. It improved to $(76.4 \%)$ in the post test. This is in accordance with Ghallab, (1994). It could also be attributed to lack of water sources in all nursing station all over the (MCH) centers, besides lack of utility rooms which may not encourage nurses to wash their hands.

Pratte, (2001) presented that hand contamination is one of the main contributing factors in the current infection threat. Contaminated hands are responsible for transmitting infections. Effective hand cleaning can significantly reduce infection rates in highrisk areas. As regards, the nurses performance through check list observation, the majority of nurses did not carry out certain procedures in relation to infection control precaution in $\mathrm{MCH}$ such as hand washing, use of protective barriers, correct disposal of needles and sharp instruments. These behaviors could be attributed to the lack of nurses knowledge and lack of disposable supplies, cleaning solutions and protective barriers.

In the present study nurses practice about a solution may be used in hand washing, equipment may be used in hand washing in table (3). The results revealed that the majority of nurses practice were adequately performed about hand washing on pre and post test while low frequency of the protective barriers was observed on pretest, frequency increased at post test. Although Reybrouck, (1994) stated that the purpose of hand washing is to remove dirt, and to reduce the load of bacteria on skin, washing soap and water removes most of transient bacteria flora in the maternal and child health centers.

Proper cleaning of instruments prior to sterilization or disinfection is essential by 
rinsing the instruments in cold water to remove organic matters. In the present study the nurses knowledge and practice about cleaning of the blood and sterilizing surgical instrument table $(2 \& 3)$ revealed that the majority of nurses are adequately prepared on it after exposure to the program. These findings disagreed with Garner \& Favero, (1986) Ghallab, (1994) and Mohammed, (1999)which revealed that almost all nurses did not carry out this technique at all.

Moreover it was also observed that nurses in some centers used only tap water and a piece of cotton in cleaning instrument. Such a technique did not result in proper cleaning of instruments from the blood and body fluids this will affect the efficiency of sterilization. Hafez,(1999) and Hooke et al,(2001) added that the role of the nurse to carry out the procedures of aseptic techniques and sterilization of instruments in a correct manner is of a prime importance to prevent surgical complications and prevent infection.

Regarding the method of sending wastes after wound dressing, the result of the present study showed that nurses' knowledge and practice low frequency of correct knowledge and practice was observed among nurses in the pre test. This may be attributed to lack of knowledge, negligence and dependence on the auxiliary workers to do it, although the practicing nurse should be conscious of the need for infection control at all times. The result agree with Ghallab, (1994) and Mohammed, (1999). Moreover, Garner, (1996) stated that all nurses must receive education and training in safe handling after wound dressing and disposal of sharp infected wastes and all other activities to prevent their exposure to microorganisms and others. In addition, the nursing staff should be trained for aseptic techniques. The education program should be regularly, updated in view of changing knowledge and work practice.
A study was conducted in UK Department of the Environment, (1991) revealed that wastes should be stored safely in a manner to prevent accidental spillage, accidental or weather destroying the bag and wear of container. London Waste Regulation Authority, (1989) reported that clinical waste should be transported safely in cleaned or disinfected vehicle designated of that task.

As regards the health team knowledge concerning the method of sending solid linen from the ward to the laundry, the result of the our study showed that the health team knowledge about the correct method of sending solid linen from the ward to the laundry was $56.9 \%$ in table (2). This deficiency may be due to the absence of governing polices and procedures. When linen is to be collected and changed by the auxiliary persons, it is collected in the bathroom and washed manually and this may be due to lack of facilities and ignorance of the auxiliary personnel about occupational hazards. These result agree with (Ghallab, 1994 and Mohammed, 1999).

Although (Ayliffe et al., 1992) stated that nurses should be exposed to training to raise their awareness about the importance of correct bagging procedures and prevention of infection. Solid linen should be placed in an impervious laundry bag in the clients' room (OSHA., 1991).

As regards the nurses' performance, the results revealed that the majority of the nurses did not carry out or perform certain procedures in relation to infection control precaution in (MCH) centers such as use of protective barriers e.g., gloves, mask, apron and correct disposal of needles and sharp instruments table (3). These behaviors could be attributed to the lack of nurses' knowledge and lack of supplies. This result agrees with Ghallab, (1994) Elewy, (1997) and Mohammed, (1999). Garner, (1996) stated that when participating in a procedure 
must create droplet or splashing or spraying of blood and body fluids a nurse must wear protective barriers such as masks, gloves, eye wear to prevent transmission of infection.

Thus, it can be argued that suggested training program is effective in improving nurses' knowledge and practice regarding infection control.

Conclusion; low frequency of correct answer was observed among nurses in the pre test, the percentage of correct answer was increased in the post test related to knowledge and practice. Recommendations ; periodic refresher training courses should be provided in order to keep nurses of up dating knowledge and practice regarding to infection control.

\section{REFERENCE:}

Ayliffe GA. Lowbury EJ. Geddes AM. And Williams JD. (1992): Control of Hospital Infection. Apractical (handbook, $3^{\text {rd }}$ Edition. London, Chapman\& Hall p12.

Centers for Disease Control and Prevention. CDC(2002): Guideline for hand hygiene in health care setting. Morbidity and Mortality Weekly report 51 (October, 2002) $1,14$.

Colleg, K.(1994):Nurses hand contamination practice results of a local study. Journal Hosp Soc, 28:15-30.

Department of Health. (1991): Protecting AIDsHIV infected health workers: Occupational guidance for health care workers their physicians and employers. Recommendation for the Expert Advisory Group on Aids. London.

Department of the Environment, (1991): Waste Management the duty of care. A code of practice, issued in accordance with Environmental protection Act 1990 London: HOMS.
Elewy E.A. (1997): Assessment of Nurses Knowledge Regarding Infection Control Precaution at Assiut University Hospital. Pp. 14, 85.

Garner JS. (1996): The Hospital Infection Control Practices. Advisory Committee. Guidelines for Isolation Precaution in Hospitals, 17: (1), 53-80.

Ghallab S. (1994): Developing and implementing an in-service education on aseptic techniques and principles of sterilization for nurses working in surgical departments of Assiut University Hospitals.

Gould DJ. (1994): Making sense of hand hygiene. Nursing Times, July 27, Volume 90, No. 30. Kings college, London.

Griffiths A.J. and Ward K.(1995):Principles of infection control practices. Introduction, Scutri Press, London.

Hafez S.M. (1999): A application of Education program For Nurses about Infection Control Precaution with AIDS and virus Hepatitis- B. In Assiut University Hospital. Submitted For Partial Fulfillment of the Doctorate Degree in Obstetric and Gynecology Nursing

Hambraeus A. (1995): International Federation of Infection Control. Education Program for Infection Controls: Basic Concepts and training.

Health and safety Executive, (1989): Personal Protective Equipment at Work Regulations: Guidance on regulation. London: The stationary office. Nursing Times 2001, vol. 97, No.13.

Hill, D. (1992): Continuing are observed, elderly long stay patients have particularly high infection risks. Nursing Times, 88(50).

Hooke E, Bennett L, and Dwyer R, (2001): Nurse practitioners: an evaluation of the extended role of nurses at the Kirketon 
Road Centre in Sydney, Australia; Aust J Adv Nurs 20001 Mar- May; 18(3): 20-8.

Iganz, S. (1994): The significance of hand drying in prevention of infection. Nursing Times 1996 November 23, Vol. 90, No. 47. Jewish B.(1997): Fundamental of Nursing. Fifth Edition, Chapter Asepsis PP. 535-583. Mosby, A Harcourt Health Sciences Company.

London Waste Regulation Authority, (1989): Guideline for the Segregation, Handling and Transport of Clinical Waste. Principles of infection control practice. Clinical waste pp27-30. Waste Regulation Authority.

Mickos-Schild, S (1998): What every health care provider needs to know. Today's surgical nurse; 20:3, 13-16 Nursing Times. November 15, Volume 97.No.98.

Mohammed A. (1999): Application of education program for nurses about infection control precautions with AIDs and Virus Hepatitis-B in Assiut University Hospital. P 24- 29.

National Survey of Maternal Mortality, (1994): Maternal Child Health. Competency based curriculum. Faculties of Nursing; University of Alexandria \& University of Cairo. In Collaboration with MOHP,USAIDS and JSI Egypt 20002001. pp.16-36.

Nicholson, (1997): Screening staff for MRSAleads:Hs executive. Nursing Times November 15 (2001), Vol.97.No.46.



blood borne pathogens, Federal Register $56(235)$ : 64175.

Pratte, RJ (2001):The Development of National Evidence- Based Guidelines for Prevention Hospital Acquired Infection in England. London: Thomas vally University. Available at WWW. Epic ivu. Ac uk.

Reybrouck, G. (1994): Hand washing and disinfection. Journal of Hospital Infection. 4:103-110.

Rutala and Shafer (1996):General information on cleaning, disinfection and sterilization. In APIC infection control and applied epidemiology: Principles and practices, St. Louis, 1996, Mosby.

Taylor C. Lillis C. and LeMone P.(1997):Fundamental of Nursing Care. The art and science of nursing care. Chapter 28.Asepsis. Third edition. Mosby, London, PP 557- 559.

Thomllison D, Millward S, and Barnmatt J. (1993): A clinical infection control Audit Program; Evaluation of an audit tool used by infection control nurses to monitor standards and assess effective training. Journal Hospital Infection, 24; 219-32.

Turner JG, Booth WC, Brown KC, and Williamson KM (1990): National survey of infection control practioners educational needs. Am J infect Cont. 18; 86-92.

WHO, (1991):Geneva, Weekly Epidemiological Record, No. 26,28 June 66, P 189-196. 
تقييم برنامج تعليمي تدريبي للممرضات العاملات بمر اكز الأمومة والطقولة بمدينة أسيوط فيما يتعلق بمكافحة العدوى العاب يمز الأمون

أسماء كمال حسن" ، فرج ححم مفتاح **، سوسن محم علاء الدين *، سعاد سيد * قسم تمريض صحة المجتمع - كلية التمريض، ** قسم الصحة العامة - كلية الطب - جامعة أسيوط

هدفت هذه الدراسة إلى تقييم برنامج تعليمي تدريبي للممرضات العاملات بمراكز الأمومة والطفولة بمدينة أسيوط

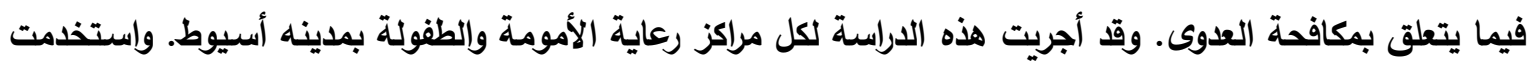


الثخصية قبل وبعد البرنامج وذلك لقياس مستوى معرفة الممرضات بمكافحة العدوى مثل تعريف التعقيم، العزل



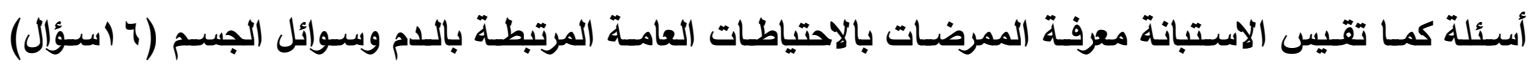

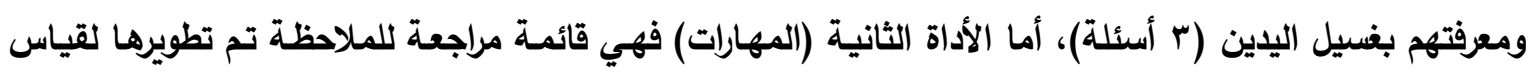

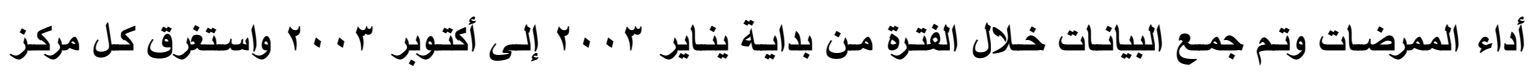
شهرين

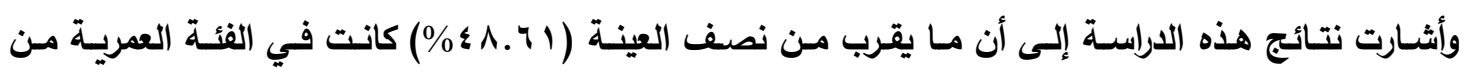

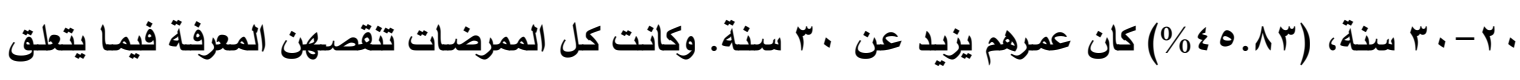



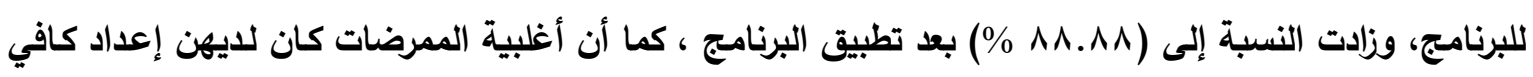

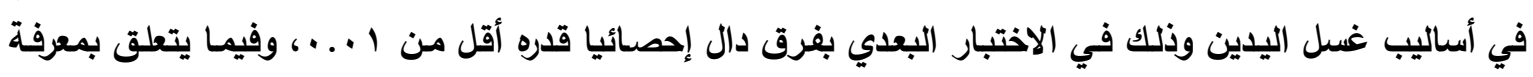

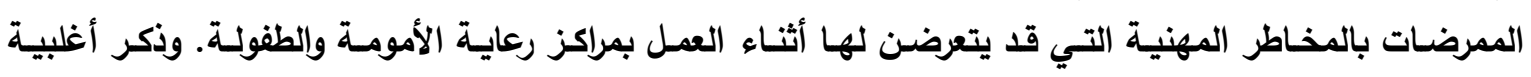

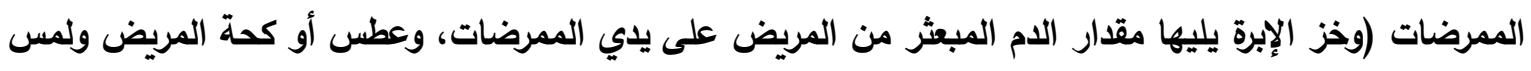
جلد المريض ).

وقد كشفت هذه الدراسـة ضعف المستوى العلمي والمهارى للممرضـات ذات العلاقة بمكافحة العدوى، وتلعب



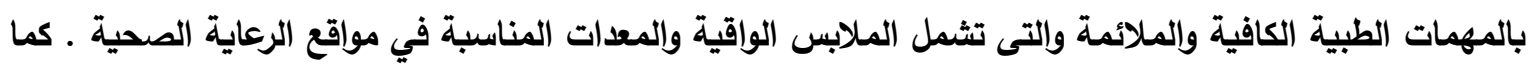


بمعلوماتهن ومهاراتهن مما سينعكس بصورة إيجابية على الخدمات الصحية المقدمة للمرضى. 